\title{
Aula inaugural
}

Senhores,

Por indicação do ilustrado catedrático Dr. F. Vergueiro STEIDEL, mestre insigne de direito e de civismo, que nunca admirareis em demasia admirando o mais que puderdes, um dos patricios que, no professorado, mais assinalados serviços tem prestado ao nosso país - assumo a regência da cadeira de direito comercial terrestre, como substituto, matéria que êle vinha prelecionando, na ausência do ilustrado catedrático Dr. Octavio Mendes, ora fóra do Brasil, em gôzo de licença.

Estou a ver, nos vossos olhos, a expectativa de quem vai experimentar novidade. Tinheis professor já feito, que vos dava preleções modelares; tendes, hoje, um livre docente (mercê da refórma do ensino, decretada pelo poder executivo, supressora, por medida de economia, dos cargos de professores substitutos) a reger a cadeira que ainda guarda os vestigios da palavra iluminada de BrasiLio MAcHADO, nome que relembro com saudade.

Com a prática do ensino é que se faz o professor. Para ensinar não basta saber. E' necessário o condão misterioso que põe em vibração os espiritos para que entre êles se opére a transfusão dos conhecimentos. Ensinar é muito 
mais do que semear. O que esparze as sementes conta com a colaboração da terra para recolher os frutos. 0 semeador é operário que colhe, com o correr dos dias, o resultado do seu esforço. O professor tem que colher os frutos quáse ao lançar a semente. $O$ conhecimento adquire-se no mesmo instante em que a idéia é posta em circulação. $\mathrm{O}$ raciocinio é rápido como o relampago. Se o estampido se ouve depois do corisco é porque a luz se propaga com maior velocidade que o som.

E' qualidade do professor, ademais do conhecimento da disciplina, a clareza, a segurança, a correção da fráse, a precisão do discurso, o descortino, perfeita associação de idéias, raciocinio fluente e harmônico.

Tenho, bem nitida, a noção de que aind'a não sou professor. Sou, como vós, estudante. Porque já percorri provincias da ciência jurídica, que ides percorrer agora, serei, nessa jornada, 'vosso cicerone. Caminharemos juntos, guiados pela minha experiência. Seguir-vos-ei com a minha simpatia, com o melhor da minha dedicação e, ao fim, dar-me-ei por muito feliz se tiver alcançado a vossa estima, o vosso respeito, a vossa amizade.

Estudaremos juntos o progrâma de direito comercial elaborado pelo titular desta cadeira e aprovado pela douta Congregação desta Academia, cujas tradições saberemos honrar. Estudaremos. Êste verbo tem pêso excessivo aos ouvidos dos moços, sonoridade metálica. Mas certamente que estudaremos. Eu e vós. Vós estudareis. Porque, em verdade, ainda não se descobriu outro processo de aprender. Estudando é que se aprende. Aprendendo é que se sabe ou, ao menos, se adquire a presunção de saber.

Só então, e por êsse único e antiquissimo processo, é que alcançareis as vossas convicções jurídicas, virtude que, em regra, falece aos advogados e, tantas vezes, aos magistrados. $\mathrm{O}$ asserto é um tanto rigoroso, eu o reconheço, mas, para sossêgo de vosso espírito, vos declaro que não 
é meu. E' de Cesare Vivante, que se referia aos advogados e magistrados italianos, acrescentando: "O advogado, que não tem convicções jurídicas, está sempre pronto para fazer suas as convicções do cliente, seguindo-o em demandas em que perderá dinheiro e paz. O juiz, que não tem convicções jurídicas e fórma-as de caso em caso, está sujeito a sofrer a influência dos homens de poder ou dos amigos que o cercam: a falada corrução dos magistrados não tem, por força, outra causa senão a sua ignorância: êles se deixam dominar pela autoridade dos patrocinantes porque, para quem sabe pouco, todas as soluções são boas" (1).

Isso é assim, também, e desgraçad'amente, no nosso país, em que o desapêgo pelas convicções jurídicas e malbarateamento delas vão transformando em territóric sem rei, nem roque. A carência de convicções, ou jurídicas, ou econômicas, ou financeiras, notadamente a ausência de convicções politicas, eis o grande mal brasileiro. Vivemos ao Deus dará, em empirismo espantoso, fazendo experiências arriscadas, mas cortando, com elas, o cérne da nacionalidade. Erros provocam outros erros porque, para os que não têm a certeza prévia dos atos que praticam, dar nova feição aos problemas, criando variantes, abrindo encruzilhadas, é resolvê-los. $O$ engano é funesto.

Detenhamo-nos um pouco, correndo os olhos para a história pátria. Decretada, por exigências do sentimento de liberalidade e de humanidade do país, a abolição da escravatura, precipitou-se o movimento republicâno, que abateu o trôno. Implantado o govêrno democrático, que estava nas cogitações de nossos homens públicos, instaurou-se o sistema presidencial, como fórma de govêrno — a república federal, sob o regime representativo. Educado em regime parlamentar, de certo modo adaptado às contin-

1. Cesare Vivante, I difetti sociali del Codice di Commercio, Prolusione. Fratelli Bocca Editori (Torino, 1899), pág. 18. 
gências do país, regime de ampla discussão e larga publicidade, passou o Brasil para sistema ou regime politico que não estava entre nós convenientemente conhecido, nem era o indicado pelas convicções jurídicas dos grandes estadistas e politicos nacionais. Foi a nossa primeira experiência, que ainda não terminou, porque até agora, no entender dos mais fervorosos adeptos, não foi convenientemente aplicado. Indiscutivel é, no entanto, que êle degenerou em fórma de govêrno, que póde ser tudo, menos a representativa. Os três poderes politicos, que devem ser harmônicos e independentes entre si, como órgãos da soberania nacional, ficaram praticamente reduzidos a um único - o executivo, porque o legislativo se despiu de suas funções, por suicidio politico, e o judiciario, pelo executivo constituido, foi posto à margem.

Tinha que vir necessariamente dêsse estado de coisas, dessa anomalía politica sem igual, o desmoronamento. Sem principios conhecidos, sem convicções jurídicas, sem programas definidos, sucedendo-se os governos, sem roteiros conhecidos, se deixaram envolver na têia de aranha da politicagem e se entregaram à politicalha, adversária acerrima das administrações laboriosas e fecundas. Chegaram, mesmo, a ser negociados os altos interêsses nacionais. Não dispondo de partidos constituidos, representativos das grandes correntes da opinião pública, limitaram-se os govêrnos a resolver os casos politicos regionais, sobretudo depois que, com o govêrno do malogrado Afonso Pena, se encerrou o ciclo famoso das três grandes presidencias paulistas, que, pela unidade de ação e segurança de métodos, traçaram a fáse aurea do regime republicano entre nós.

Fez-se, para os cargos da administração nacional, seleção de tal ordem, que o proprio presidente da República, em mensagem que, em 3 de maio de 1924, dirigiu ao Congresso Nacional, reconheceu que o país se ressente, inegàvelmente, da falta de homens de govêrno, que a República não conseguiu formar. 
Será isso por culpa dos homens? Evidentemente, não. Porque isso se deve ao regime existente, por força do qual, sendo embóra república federativa, todo o país é administrado, de quatro em quatro anos, por um único homem, único responsavel por seus atos e dêles o único juiz; e porque, na realidade, estando êle acima dos outros dois poderes, que êle cria, agita e conduz, êstes não lhe podern exigir prestação de contas e nem êle lhas prestaria.

Por mimetismo singular, o país, durante cada quatriênio, como que se torna a imagem e semelhança de seu presidente, pelo seu cérebro pensando, pela sua vontade agindo, por suas paixões se revelando.

Tal não aconteceria se o presidente, em vez de dirigir o país de acôrdo com o partido ou com o agrupamento oca. sional de partidos, que the deu o govêrno, o regesse de acôrdo com o próprio país, encaminhando-o para a realizacão de suas mais altas aspirações, respeitando as suas convicções politicas, sociais, cientificas, financeiras, religiosas. A função do presidente deve ser eminentemente arbitral, homem que sai dum partido ou conglomerado politico para a mais alta investidura politica e administrativa.

De debatermo-nos de experiência em experiência, por falta de convicções profundas, chegámos ao estado atual, de completo eclipse das leis. 0 estado de sítio tornou-se. estado normal, duradoiro, quáse definitivo, comprovando que o país se ressente da escassez de homens de govêrno. $\mathrm{E}$ quando todos os brasileiros, aflitos, anseiam pela volta do regime de garantías constitucionais, a mais alta autoridade, dispondo embóra de maiores poderes que muitos rêis, governando com o estado de sitio, tendo todo o país às suas órdens, nêle pondo e dêle dispondo, se dirige ao Congresso Nacional reclamando a medida suprema da pena de morte!

Mas isto, senhores, é retrocesso!

Tivêmo-la, no regime encerrado pelo movimento de 15 de novembro de 1889 , incorporada ao nosso sistema re- 
pressivo. "Conquanto" - e estas são palavras de JoÃo BARBalHo, o nosso grande constitucionalista - "conquanto a Constituição imperial, inspirando-se em principios humanitários, tivesse abolido "todas as penas cruéis" (art. 179, n. XIX), e à pena de morte não se póde negar êsse caráter, entendeu-se que esta devia subsistir e, se bem com parcimônia, a legislação ordinária a consagrava. Não era, porém, aplicada a crimes políticos, e a lei como que se envergonhava de empregá-la mesmo noutros delitos. Não queria demorada a execução e proibia que esta se fizesse em véspera de dia santo, domingo ou feriado nacional (cod. crim., art. 39). A fôrca era levantada somente quando havia execução principal a fazer-se, para não estar continuadamente à vista do público, dizia o aviso de 17 de junho de 1831. E devia ser demolida logo depois da execução. Não havia entre os auxiliares da justiça criminal o carrasco, êsse agente da morte em nome da lei. A tarefa de matar por mandado do juiz era de momento confiada a algum réu sentenciado (de ordinário, escravo) e se nenhum havia no lugar ou havendo não se prestava a isso, recorría-se a outro distrito (Aviso de 30 de junho de 1836). Exigia-se para a condenação unanimidade de votos do juri (art. 332 do cod. do proc. crim., e art. 29, $\S 1$, da lei n. 2.033, de 20 de setembro de 1871). Da sentença dava-se, com suspensão, e ex-officio se a parte o não interpunha, o recurso de graça (art. 3 da lei de 11 de setembro de 1836), sem cuja decisão não se cumpria a pena capital. Tais providências não eram simples cautelas em prol da inocência, nem benevolência para com os réus convictos; exprimiam também e principalmente o sobressalto e susto de que se possuía o poder público na temerária e irreparável aplicação de tão desumana e horrorosa pena. Não a tolerava o estado de nossos costumes e foram-se tornando raras as execuções a ponto de se poder afirmar com a comissão do Congresso Constituinte ao propôr a abolição de tal pena, que ela de fato estava 
abolida entre nós. Repugnava ela ao júri, expressão da consciência pública; repugnava ao magistrado, órgão do direito; repugnava aos que eram chamados a executá-la, como de suas recusas se evidenciava; repugnava ao imperante, em honra sua se diga, como o mostravam os decretos de comutação. Todios a condenavam; a República executou essa condenação, suprimindo a pena que na frase do insigne BEcGaria não era mais que o crime de assassinato legal" (2).

Suprimindo-a, o art. 72, $\S 21$, de nossa Constituição ressalvou, no entanto, as disposições da legislação militar em tempo de guerra.

Mas a República, no sentir daquêles que prestaram o solêne compromisso de mantê-la tal qual está focalizada na Constituição, está cansada de ser liberal. Amordaçou a imprensa, a única tribuna livre que tinha ficado ì disposição do país e pela qual êle manifestava sua opinião e criticava os atos do govêrno. Agora, depois de trinta anos de democracía, quer êste restabelecer a pena de morte especialmente para os réus de crime politico!

A jornada revisionista, iniciada por Silveira Martins, depois encaminhada por Prudente de Morais, por Assis Brasil, por LaUro Sodré e, ultimamente, apoiada pelo imorredouro Rui Barbosa, parece, afinal, e de certo modo, vencedora. Mas não é revisão, organização política em novos moldes o que pleitêia o presidente da República. O que êle disputa nem mesmo é reforma: são retoques, remendos para se cercearem os direitos individuais e para dar ao executivo maiores poderes dos que atualmente êle tém. Não há, entretanto, pior momento do que o atual para a realização da refórma indicada pelo executivo. Se a Constituição, como o disse Frei JoaQurm Antônio do Amor Divino Caneca, o patriota que, condenado à morte, não

2. JoÃo Barbalho, Comentários à Constituição Federal Brasileir'a, 1.a ed., pág. 32\%. 
encontrou carrascos que o quisessem matar, sugerindo aos seus algozes que o espingardeassem; se Constituição é o pacto que entre si fazem os homens quando se ajustam para viver em sociedade - claro é que ela não póde ser revista, nẹ modificada, sem que a revisão, ou a modificação, seja a resultante dias convicções jurídicas e políticas dos brasileiros. Façamos votos por que êsse melindroso problema seja debatido no Congresso Nacional somente. depois de cessado o estado de sitio, para que livremente se manifeste a opinião nacional. Se, no entanto, se insistir nela, a todo transe, principalmente para a restauração da pena de morte, que fique, ao menos, o nosso protesto, lançado nesta casa, onde se ensina e onde se aprende o direito, e sob cujas arcadas se debateram todos os grandes problemas brasileiros.

A vossa geração, senhores, que apenas surge, mas que terá de solucionar as questões, que ora nos preocupam, precisa preparar-se para êsse mistér. Necessario será, portanto, que os que se dedicam aos negócios públicos assumam os cargos, que o futuro lhes destinar, levando para êles convicções jurídicas, para que se não reproduzam os êrros e os males que ora nos infelicitam. Isso, repito, somente conseguireis, estudandio.

Era o Brasil até há pouco, e São Paulo especialmente, essencialmente agrícola. Vivia da exploração do seu sólo. Operou-se, todavia, grande modificação no nosso modo de viver. Intensificou-se de tal sorte o nosso comércio, tais proporções tomou, que provocou o desenvolvimento indus. trial do país. Novos hábitos. Novas tendências. Nova orientação. Novos rumos abriram-se para o nosso sisteina econômico e financeiro. Novos mercados se ofereceram para os nossos produtos.

Esse florescimento comercial e industrial, trazendo novos hábitos, criou novas necessidades. Relações jurídicas, antes desconhecidas ou apenas teoricamente conhecicias, 
deram lugar à criação de órgãos, aparelhos e instituições, que demandam estudos aprofundiados.

0 direito comercial, compendiado no código de 25 de junho de 1850, evolveu. E o próprio código, dos meihores do tempo em que foi elaborado, com o correr dos tempos foi recebendo tais golpes que, a bem dizer, dêle nos ficou apenas meio código. Ele estacionou. À sua ilharga, porém, foram aparecendo leis especiais, quer modificando e ampliando institutos nêle regulados, quer criando e disiiplinando outros que êle não podia prever. Tornou-se, dessarte, fragmentário, não consolidado o nosso direito comercial, que assim continuará até que o Congresso Nacional, reintegrando-se na sua função própria e privativa de legislar, da qual se desfez, discuta o projeto há mais de doze anos apresentado pelo saudoso comercialista JERculano Marcos Inglez de Souza, e que ainda não saiu da cnmissão especial nomeada pelo Senado Federal.

Já conheceis a história do comércio e do direito comercial, desde os mais remotos tempos até nossos dias, e vistes que a história do comércio é como que o complemento da história política, que deve, no dizer de Gino Luzzato, como capitulo da história da civilização, constituir o contôrno, o fundo do quadro de que os acontecimentos politicos ocupam sempre a parte central (3). Fenómeno econômico, além de meio de difusão da civilização, exerce êle sua função sob vários aspectos, pondo em cìrculação as riquezas e os bens de que careceram os povos para o seu desenvolvimento, em todas as éras, caminhando nas rotas abertas pelos conquistadores.

As regras do comércio marítimo do Mediterrâneo, compendiadas na Lei Ródia, foram-se aperfeiçoando e alargando, ̀̀ proporção que o comércio aumentava. Os mercadores, provendo à defêsa de seus interêsses comuns, organizaram-se em corporações; e estas, intervindo no go-

3. Gino Luzzatro, Storia del Commercio, vol. I - Dall antichitá al rindscimento ed. G. Barbera (Florênça, 1914), pag. 1, n. 1. 
vêrno das comunas, legislaram e criaram tribunais especiais para o processo e rápido julgamento de suas controvérsias, aplicando os usos em voga e a equidade, em vez das rígidas normas do direito civil.

Direito especial, direito de classe, o direito comercial ou mercantil era, a principio, estritamente profissional. Ganhou novas fórmulas, adquiriu certa expansibilidade com a codificação das regras que constituiram o jus mercatorum.

Tendes, pelo desenvolvimento dos dois primeiros pontos do progrâma, já larga e exaustivamente explicados, notícia de como êle se propagou até constituir, em nossos dias, um dos ramos do direito privado, do qual se tornou pioneiro.

Iniciaremos, portanto, o nosso curso, explicando o ponto terceiro, em que se trata da definição e da autonomía do direito comercial. Nêle, de inlício, se pergunta se é, ou não, autônomo o direito comercial: é a elegantíssima controvérsia sôbre a unificação do direito privado.

Deixando êsse assunto para ser tratado na nossa primeira aula, eu vos dirijo, senhores, as minhas saudações e o meu agradecimento pelas palavras gentís do vosso orador, com que me recebestes. 